\title{
Serum total proteins and related electrophoretic fractions in growing foals
}

\author{
M. Quartuccio, F. Arfuso, C. Giannetto, E. Giudice, S. Di Pietro, and G. Piccione \\ Department of Veterinary Sciences, Polo Universitario Annunziata, University of Messina, Messina, Italy \\ Correspondence to: G. Piccione (giuseppe.piccione@unime.it)
}

Received: 9 December 2014 - Accepted: 3 March 2015 - Published: 26 March 2015

\begin{abstract}
The aim of this study was to evaluate the changes of serum total proteins, albumin, $\alpha 1-, \alpha 2-, \beta 1-, \beta 2$ and $\gamma$-globulins in growing foals during the first month of life. Nine clinically healthy foals (five females and four males, mean body weight $39.00 \pm 3.50 \mathrm{~kg}$ ) were enrolled in the study. From each animal, blood samples were collected by jugular venipuncture every 3 days during the first month of life starting from the day of birth. Serum concentration of total proteins, albumin, $\alpha 1, \alpha 2, \beta 1, \beta 2$ and $\gamma$-globulins was assessed. One-way repeated measures analysis of variance (ANOVA), followed by Bonferroni post hoc comparison test, was used to determine statistically significant effect of the day of life on studied parameters. A statistically significant effect of the day of life on serum total proteins $(P<0.0001)$, albumin $(P<0.0001)$ and $\gamma$-globulins $(P<0.005)$ was observed during the first month of life. Our findings emphasize the importance of establishing different reference intervals for serum electrophoretic protein profiles in growing foals based on their physiological status.

This study provides useful information that could help clinicians to better interpret clinical data and diagnose equine neonatal disease.
\end{abstract}

\section{Introduction}

The neonatal period is a transitional phase between the foetal and newborn periods during which homeostatic mechanisms complete their maturation, allowing the foal's adaptation to extra-uterine life (Rossdale, 2004). The major adaptation of the newborn is the change from placental nutrition to alimentation. At birth, the oral nutrient intake becomes the sole source of nutrition; the colostrum's intake shortly after birth is critical for newborn survival as it ensures the transfer of passive immunity (Knottenbelt et al., 2004). The composition of the mammary secretion changes considerably with time (Oftedal et al., 1983) and in the first hours after birth the colostrum is rich in proteins represented mainly by immunoglobulins (Ig). For species having an epiteliochoral placenta, such as horses, the process of Ig transfer from the mother's colostrums is of paramount importance for the survival of newborn. Effectively, neonatal foals are hypoimmunecompetent at birth and are characterized by a small store of energy for heat production and metabolism (Sjaastad et al., 2003; Curcio and Nogueira, 2012).
Total proteins contribute largely to neonate immunity and growth because of immunoglobulin content. Wide variations in the serum levels of total proteins and their fractions were showed during the first year of life in newborn animals (Sato et al., 1979; Bauer et al., 1985; Piccione et al., 2009, 2013a, b).

Some authors have shown that at birth, serum protein levels are quite low due to the minimal quantities of immunoglobulins and low albumin (Sato et al., 1979). Therefore, the newborn is in a metabolically unstable condition that makes it particularly sensitive to perinatal period diseases resulting in high mortality (Fowden et al., 2012).

It is known that a substantial proportion of neonatal diseases or deaths could be prevented by good management techniques, early intervention and diagnosis of situations that involve high risk for the newborn, such as the non-early approach and the dam's suckling of the foal (Knottenbelt et al., 2004). Moreover, detailed blood and biochemical serum reference ranges could help clinicians to better interpret clinical data and neonatal diseases and, therefore, they may be ap- 
Table 1. Mean values \pm SD (standard deviations) of serum total proteins, albumin, globulins and A / G Ratio levels in nine growing foals during the first month of life.

\begin{tabular}{|c|c|c|c|c|c|c|c|c|c|c|c|}
\hline Serum parameters & Day 1 & Day 3 & Day 6 & Day 9 & Day 12 & Day 15 & Day 18 & Day 21 & Day 24 & Day 27 & Day 30 \\
\hline Total proteins $\left(\mathrm{g} \mathrm{dL}^{-1}\right)$ & $4.52 \pm 0.27$ & $5.56 \pm 0.43^{1}$ & $5.58 \pm 0.48^{1}$ & $5.82 \pm 0.34^{1}$ & $6.15 \pm 0.65^{1}$ & $5.66 \pm 0.45^{1}$ & $5.95 \pm 0.56^{1}$ & $5.90 \pm 0.37^{1}$ & $6.17 \pm 0.39^{1}$ & $6.14 \pm 0.40^{1}$ & $6.60 \pm 0.42^{1,2}$ \\
\hline Albumin $\left(\mathrm{g} \mathrm{dL}^{-1}\right)$ & $2.29 \pm 0.09$ & $2.92 \pm 0.38^{1}$ & $2.95 \pm 0.35^{1}$ & $2.97 \pm 0.39^{1}$ & $2.96 \pm 0.56^{1}$ & $2.97 \pm 0.45^{1}$ & $3.03 \pm 0.47^{1}$ & $3.13 \pm 0.32^{1}$ & $3.09 \pm 0.55^{1}$ & $3.11 \pm 0.27^{1}$ & $3.32 \pm 0.23^{1}$ \\
\hline$\alpha 1$-Globulins $\left(\mathrm{g} \mathrm{dL}^{-1}\right)$ & $0.16 \pm 0.06$ & $0.18 \pm 0.03$ & $0.19 \pm 0.04$ & $0.19 \pm 0.04$ & $0.19 \pm 0.05$ & $0.19 \pm 0.02$ & $0.19 \pm 0.04$ & $0.20 \pm 0.05$ & $0.20 \pm 0.03$ & $0.20 \pm 0.03$ & $0.20 \pm 0.05$ \\
\hline$\alpha 2$-Globulins $\left(\mathrm{g} \mathrm{dL}^{-1}\right)$ & $0.55 \pm 0.19$ & $0.53 \pm 0.16$ & $0.54 \pm 0.25$ & $0.58 \pm 0.07$ & $0.69 \pm 0.20$ & $0.62 \pm 0.05$ & $0.55 \pm 0.13$ & $0.57 \pm 0.13$ & $0.67 \pm 0.10$ & $0.66 \pm 0.08$ & $0.63 \pm 0.08$ \\
\hline$\beta 1$-Globulins $\left(\mathrm{g} \mathrm{dL}^{-1}\right)$ & $0.51 \pm 0.06$ & $0.54 \pm 0.14$ & $0.56 \pm 0.19$ & $0.66 \pm 0.14$ & $0.67 \pm 0.17$ & $0.65 \pm 0.19$ & $0.75 \pm 0.19$ & $0.71 \pm 0.20$ & $0.71 \pm 0.21$ & $0.78 \pm 0.23$ & $0.73 \pm 0.23$ \\
\hline B2-Globulins $\left(\mathrm{g} \mathrm{dL}^{-1}\right)$ & $0.39 \pm 0.19$ & $0.30 \pm 0.15$ & $0.35 \pm 0.03$ & $0.36 \pm 0.07$ & $0.35 \pm 0.02$ & $0.34 \pm 0.07$ & $0.35 \pm 0.12$ & $0.48 \pm 0.15$ & $0.37 \pm 0.07$ & $0.33 \pm 0.05$ & $0.43 \pm 0.22$ \\
\hline$\gamma$-Globulins $\left(\mathrm{g} \mathrm{dL}^{-1}\right)$ & $0.63 \pm 0.20$ & $1.10 \pm 0.31$ & $0.99 \pm 0.19$ & $1.07 \pm 0.42$ & $1.29 \pm 0.46^{3}$ & $0.89 \pm 0.29$ & $1.09 \pm 0.51$ & $0.81 \pm 0.18$ & $1.13 \pm 0.31$ & $1.06 \pm 0.31$ & $1.29 \pm 0.39^{3}$ \\
\hline A / G ratio & $1.05 \pm 0.19$ & $1.11 \pm 0.15$ & $1.15 \pm 0.24$ & $1.06 \pm 0.24$ & $0.94 \pm 0.20$ & $1.12 \pm 0.21$ & $1.06 \pm 0.23$ & $1.13 \pm 0.11$ & $1.03 \pm 0.29$ & $1.03 \pm 0.11$ & $1.03 \pm 0.22$ \\
\hline
\end{tabular}

Significance: ${ }^{1}$ vs. day $1(P<0.0001) ;^{2}$ vs. day 3 , day $6(P<0.001)$, day 9 and day $15(P<0.05) ;{ }^{3}$ vs. day $1(P<0.01)$.

plicable to the study of preventive medicine (Aoki and Ishii, 2012).

In this study the changes of serum total proteins, albumin, $\alpha 1-, \alpha 2-, \beta 1-, \beta 2$ and $\gamma$-globulins were evaluated during the first month of life in foals in order to enhance the knowledge of dynamic homeostatic processes of the serum electrophoretic protein profile occurring during the early period of extra-uterine life.

\section{Material and methods}

Nine Italian Saddle breed foals (five females and four males; body weight at birth $39.00 \pm 3.50 \mathrm{~kg}$ ) coming from the same breeding centre located in Sicily $\left(37.46^{\circ} \mathrm{N}, 14.93^{\circ} \mathrm{E}\right)$ were enrolled in the study with the informed owner consent. All foals were born full term in spring and were kept in box with their mother under natural environmental conditions (Min Temperature of $8.5^{\circ} \mathrm{C}$; Max Temperature of $20.4^{\circ} \mathrm{C}$; Relative Humidity of $68.2 \%$ ). The foals were feed only with colostrum and maternal milk.

At birth, each foal was subjected to clinical examination (heart rate, respiratory rate, rectal temperature) and routine hematology and plasma biochemistry testing. All the foals were considered healthy and included in the study.

The same operator performed blood sampling on each foal by jugular venipuncture into vacutainer tubes (Terumo Corporation, Tokyo, Japan) without anticoagulant agent every 3 days starting from day 1 (after colostrum intake), until day 30 of life. Following standing at room temperature for $20 \mathrm{~min}$, the tubes were centrifuged at $3000 \mathrm{rpm}$ for $10 \mathrm{~min}$ and the obtained sera were stored at $-20^{\circ} \mathrm{C}$ until analysed. The concentration of serum total proteins was determined by biuret method using an automated analyser UV Spectrophotometer (SEAC, Slim, Florence, Italy). The serum protein fractions were determined using an automated system (SelVet 24, SELEO Engineering, Naples, Italy) according to the procedures described by the manufacturer and previously used for horses (Alberghina et al., 2013). The major protein fractions revealed were albumin, $\alpha 1$-, $\alpha 2-, \beta 1-, \beta 2$ - and $\gamma$-globulins.

Protocols of animal husbandry and experimentation were reviewed and approved in accordance with the standards rec- ommended by the Guide for the Care and Use of Laboratory Animals and Directive 2010/63/EU for animal experiments.

\section{Statistical analysis}

The statistical elaboration of the data for each parameter was based on the average values obtained.

Data were normally distributed $(P>0.05$, KolmogorovSmirnov test).

One-way repeated measures analysis of variance (ANOVA), followed by Bonferroni post hoc comparison test, was applied to determine the statistical effect of day of life on studied parameters. $P$ values $<0.05$ were considered statistically significant. Data were analysed using the software STATISTICA 7.5 (Statsoft, Inc., Tulsa, OK, USA).

\section{Results}

Table 1 shows mean values \pm standard deviations (SD) of serum total proteins, globulin fractions and albimin / globulins ratio (A/G) obtained from foals during the first month of life.

One-way ANOVA revealed a statistically significant effect of the day of life on serum total proteins $(P<0.0001)$, albumin $(P<0.0001)$ and $\gamma$-globulins $(P<0.005)$ during the first month of life.

In particular, serum total proteins and albumin showed the lowest levels at day 1 followed by a gradual increase until day 30.

$\gamma$-globulins showed significantly higher levels in days 12 and 30 with respect to day 1 .

No statistical significant effect of the day of life $(P>0.05)$ on $\alpha 1$-globulins, $\alpha 2$-globulins, $\beta 1$-globulins, $\beta 2$-globulins or A / G ratio was observed during the experimental period (Fig. 1).

\section{Discussion}

The evaluation of serum protein profile is an important diagnostic aid in clinical biochemistry. Abnormalities of serum protein profile must be interpreted in light of the many phys- 

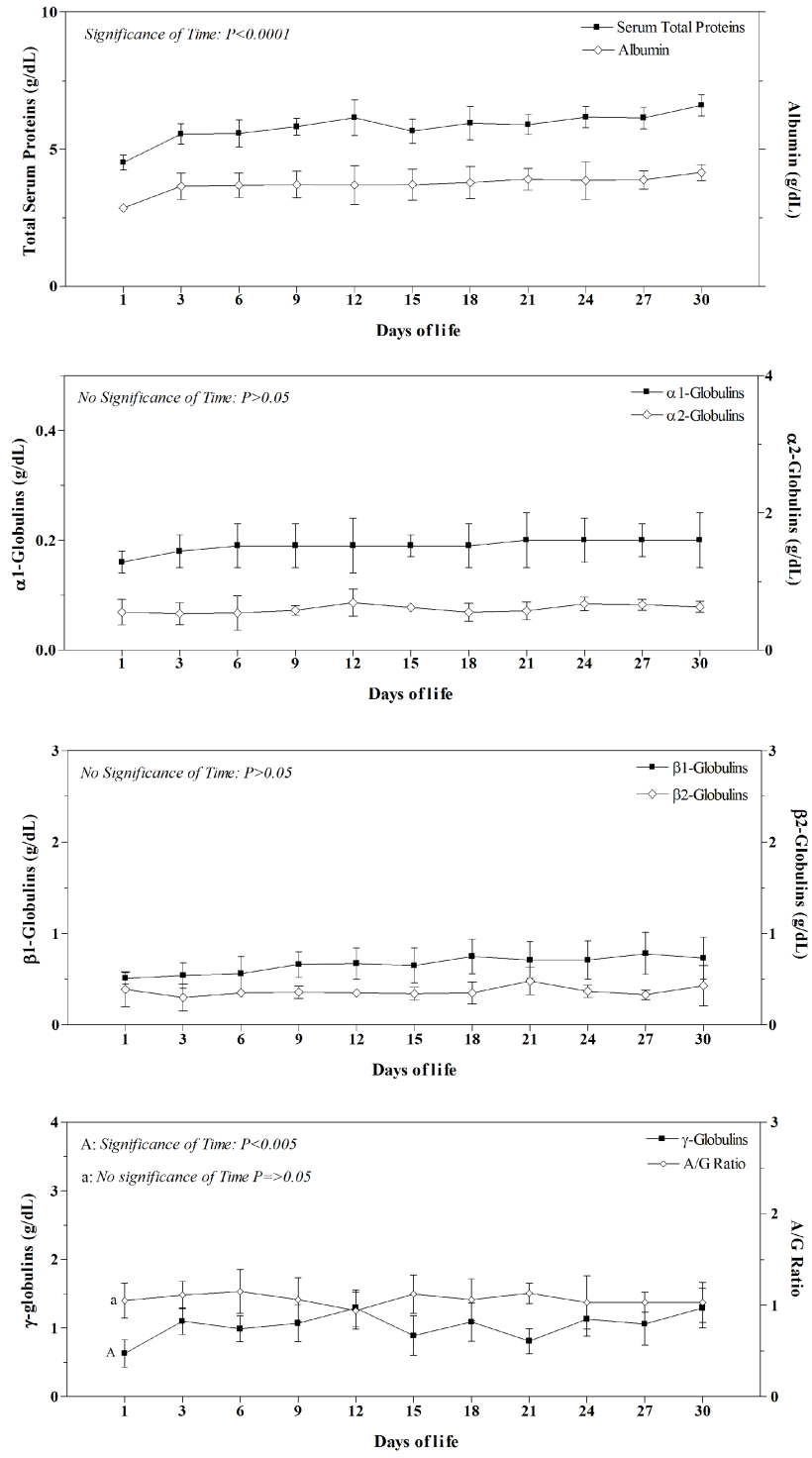

Figure 1. The pattern of serum total proteins, albumin, $\alpha 1-, \alpha 2-$, $\beta$-, $\gamma$-globulins and Ratio A / G observed during the first month of life in nine growing foals.

iological influences, such as age and development, unassociated with disease (Kaneko, 1997). In the foetus, the concentration of total proteins and albumin progressively increases while little changes in globulins and the absence of $\gamma$-globulins.

Serum total proteins, their fractions and $\mathrm{A} / \mathrm{G}$ ratio obtained in the present study were within the physiological range suggested for foals (Knottenbelt et al., 2004). According to other authors (Knottenbelt et al., 2004; Alberghina et al., 2013; Abeni et al., 2013), all serum protein electrophoretograms were characterized by the absence of a pre-albumin region and by the presence of six different bands: albumin, $\alpha 1-, \alpha 2-, \beta 1-, \beta 2-$ and $\gamma$-globulins. Our results showed a gradual increase of serum total proteins and albumin lev- els in the foals from day 1 to day 30 of life. Although no statistically significant differences in $\alpha 1-, \alpha 2-, \beta 1$ - and $\beta 2$ globulins levels were found during the experimental period, a slight increase of these electrophoretic parameters was observed from the day 1 until the day 30 of life. Moreover, significantly higher levels of $\gamma$-globulins were found in days 12 and 30 with respect to day 1 . According to other authors (Brommer et al., 2001; Axon and Palmer, 2008; Curcio and Nogueira, 2012; Piccione et al., 2013a, b), this finding demonstrated that serum total proteins and their fractions are involved in typical physiological and metabolic adjustments to early postnatal development and growth as adaptive response to various environmental factors after birth, including nutrition. The levels of these parameters are closely related to newborn ingestion of colostrum within the first hours of life (Axon and Palmer, 2008; Curcio and Nogueira, 2012).

After the first colostrum intake, substantial amounts of maternal proteins can be absorbed from the newborn's intestine during the first $24 \mathrm{~h}$. This passive maternal protein's transfer profoundly improves newborn immunity and growth (Sjaastad et al., 2003). It is known that the immune system in mammals is poorly developed at birth; thus newborns are characterized by minimal quantities of immunoglobulins (Bauer et al., 1985; Knottenbelt et al., 2004; Hurcombe et al., 2012) and are dependent on antibodies transfer from the mother through the colostrum (Bauer et al., 1985; Sjaastad et al., 2003). The colostrum contains substances that block trypsin's action and exert a suppressive effect on the foal's endogenous immunoglobulin production (Giguère and Polkes, 2005). As the maternal antibodies decline, due to normal turnover, the foal should rapidly gain immunocompetence and begin to synthesize its own immunoglobulins, reaching normal adult levels (Kaneko, 1997; Sjaastad et al., 2003). According to Ulian et al. (2014), the results of the present study highlight the foal's early capacity of protein absorption from maternal colostrums and suggest an occurred adaptive response of the foal to the extra-uterine life. In particular, the significantly higher levels of $\gamma$-globulins starting from day 12 suggested a possible activation of a foal's immune system. Essentially, it is known that antibodies produced by the foal's own immune system are detectable at 10-14 days of age (Knottenbelt et al., 2004). Moreover, the gradual increase of albumin, mainly produced in the liver, is probably related with the development of this organ (Koterba et al., 1990; Brommer et al., 2001). This confirms that animals' organ functions are in a development phase during the early neonatal period and a wide range of physiological values in different systems compensate for immaturity (Knottenbelt et al., 2004; Piccione et al., 2006, 2009; Zumbo et al., 2010). 


\section{Conclusions}

Serum total proteins and their fractions represent a tool widely used by clinicians for the diagnosis and treatment of neonatal diseases during the neonatal period. The findings of the present study emphasize the importance of establishing different reference intervals for these parameters in foals based on their physiological status and provide useful information that could help clinicians to better interpret clinical data and diagnose equine neonatal diseases.

Edited by: S. Maak

Reviewed by: three anonymous referees

\section{References}

Abeni, F., Dal Prà, A., Bertin, G., and Calamari, L.: Serum Protein Fraction in Mature Horses and Relationship With Metabolic and Hematological Parameters, J. Equine Vet. Sci., 33, 905-911, 2013.

Alberghina, D., Casella, S., Giannetto, C., Marafioti, S., and Piccione, G.: Effect of storage time and temperature on the total protein concentration and electrophoretic fractions in equine serum, Can. J. Vet. Res., 77, 293-296, 2013.

Aoki, T. and Ishii, M.: Hematological and Biochemical Profiles in Peripartum mares and Neonatal Foals (Heavy Draft Horse), J. Equine. Vet. Sci., 32, 170-176, 2012.

Axon, J. E. and Palmer, J. E.: Clinical Pathology of the Foal, Vet. Clin. N. Am.-Equine, 24, 357-385, 2008.

Bauer, J. E., Harvey, J. W., Asquith, R. L., McNulty, P. K., and Kivipelto, J.: Serum Protein Reference Values in Foals During the First Year of Life: Comparison of Chemical and Electrophoretic Methods, Vet. Clin. Pathol., 14, 14-22, 1985.

Brommer, H., Sloet van Oldruitenborgh-Oosterbaan, M. M., and Kessels, B.: Haematology: Haematological and blood biochemical characteristics of Dutch warmblood foals managed under three different rearing conditions from birth to 5 months of age, Vet. Quart., 23, 92-95, 2001.

Curcio, B. R. and Nogueira, C. E. W.: Newborn adaptations and healthcare throughout the first age of the foal, Anim. Reprod., 9, 182-187, 2012.

Fowden, A. L., Forhead, A. J., and Ousey, J. C.: Endocrine adaptations in the foal over the perinatal period, Equine Vet. J., 44 (Suppl.), 130-139, 2012.

Giguère, S. and Polkes, A. C.: Immunologic Disorders in Neonatal Foals, Vet. Clin. N. Am.-Equine, 21, 241-272, 2005.

Hurcombe, S. D. A., Matthews, A. L., Scott, V. H. L., Williams, J. M., Kohn, C. W., and Toribio, R. E.: Serum protein concentrations as predictors of serum immunoglobulin $\mathrm{G}$ concentration in neonatal foals, J. Vet. Emerg. Crit. Car., 22, 573-579, 2012.
Kaneko, J. J.: Serum Proteins and the Dysproteinemias, in: Clinical Biochemistry of Domestic Animals, edited by: Kaneko, J. J., Harvey, J. W., and Bruss, M. L., 5th ed., San Diego, USA, 117138, 1997.

Knottenbelt, D. C., Holdstock, N., and Madigan, J. E.: Equine Neonatology: Medicine and Surgery, 1st ed., Edinburgh, London, New York, Oxford, Philadelphia, St. Louis, Sydney, Toronto: Saunders, 2004.

Koterba, A. M., Drummond, W. H., and Kosch, P. C.: Equine Clinical Neonatology. Philadelphia/London, 168-169, 561-587, 602614, 1990.

Oftedal, O. T., Hintz, H. F., and Schryver, H. F.: Lactation in the Horse: Milk Composition and Intake by Foals, J. Nutr., 113, 2096-2106, 1983.

Piccione, G., Costa, A., Bertolucci, C., Borruso, M., Pennisi, P., and Caola, G.: Acid-base balance modifications in the lamb and goat kids during the first week of life, Small Rumin. Res., 63, 304 308, 2006.

Piccione, G., Casella, S., Giannetto, C., Vazzana, I., Niutta, P. P., and Giudice, E.: Influence of age on profile of serum proteins in the calf, Acta Vet.-Beograd., 59, 413-422, 2009.

Piccione, G., Arfuso, F., Monteverde, V., Vazzana, I., Zumbo, A., and Faggio, C.: Monitoring of some metabolic parameters in Comisana lambs during the neonatal period, Large Anim. Rev., 19, 133-137, 2013a.

Piccione, G., Arfuso, F., Faggio, C., Casella, S., Zumbo, A., and Panzera, M.: Serum proteins profile in Comisana lambs during the first month of life, Arch. Tierz., 56, 742-750, 2013b.

Rossdale, P. D.: The Maladjusted Foal: Influence of Intrauterine Growth Retardation and Birth Trauma, Proceedings of the 50th Annual Convention of the American Association of Equine Practitioners, Denver, CO, USA, 75-126, 2004.

Sato, T., Oda, K., and Kubo, M.: Hematological and biochemical values of thoroughbred foals in the first six months of life, Cornell Vet., 69, 3-19, 1979.

Sjaastad, ØV., Hove, K., and Sand, O.: Physiology of domestic animals, 1st ed., Oslo, Norway, 2003.

Ulian, C. M. V., Fernandes, S., Ramos, P. R. R., Dias, A., Lourenço, M. L. G., and Chiacchio, S. B.: Evaluation of colostral absorption in neonates of Bergamacia breed, Arq. Bras. Med. Vet. Zootec., 66, 705-712, 2014 (in Portuguese).

Zumbo, A., Casella, S., Di Rosa, A., Scianò, S., Fazio, F., and Piccione, G.: Levels of serum osteocalcin and some electrolytes in foal during the first six months of life, Arch. Tierz., 53, 239-241, 2010. 